\title{
SULTAN SUMBAWA POLITICAL COMMUNICATION PATTERN IN MANAGING THE GOVERNMENT (Study of Sultan Kaharuddin III's Government)
}

\author{
Ofi Hidayat, Anang Sujoko, \& Maulina Pia Wulandari \\ Communication Department, Faculty of Social and Political Science. \\ Brawijaya University \\ Email: Ofihidayat1992@gmail.com
}

\begin{abstract}
The role of political communication in running a government is a way to achieve a goal. Political communication in Indonesia has existed since the time of the ancient Javanese kingdom. The study of political communication in Asia, especially in Indonesia, is still not too famous as in Western countries, the study of political correspondence that develops in Indonesia has more to do with modern governance based on the concept of Western political studies. In this study, researchers will examine what forms of social-political communication exist in Indonesia, especially in the former Sultanate. The government of Sultan Kaharuddin III, who led the Sultanate of Sumbawa, was chosen as the object of study this time. This research was conducted because during the reign of Sultan Sumbawa, when it used a government system that adopted Islamic values and at that time also was a transition period for the independence of the Republic of Indonesia, then the Sultanate of Sumbawa only joined the Republic of Indonesia in 1950. This research will be examined using qualitative research methods. Researchers will look for how the form of political communication by Sultan Sumbawa using data collection techniques by observation, interviews with informants, and other supporting data collection. Researchers will interpret the phenomena that occur by using phenomenology. The results of this study describe the form of Sultan Sumbawa's political communication that uses the noble values of social philosophy and is based on Islamic values in running the government. The use of local arts and traditions has also become one of the political communication media used to achieve goals in the government system. So this is a distinguishing factor between the Sumbawa Sultanate and other Sultanates in Indonesia.
\end{abstract}

Keywords : Political Communication, Traditional Culture, Sumbawa Sultanate, Political Goverment

\section{A. INTRODUCTION}

The history of the formation of the Republic of Indonesia cannot be separated from the existence of political practices in it. Political practices occurred in the ancient Mataram region of Central Java to East Java (Achmad, 2016). Politics that happened during the kingdom even the Sultanate has some form of political communication both related to power to governmental policy. Catlin (Sahreza, 2018) says that politics is related to ability and the holders of power or authority. During the leadership of Sanjaya 732 AD, the ancient Mataram kingdom of the Central Java period had power in the agrarian field so that the policy at that time was influential in the economic and agricultural growth sector (Achmad, 2016).

Politics carried out by the leaders of the Hindu kingdom until the Islamic Sultanate was also carried out by leaders or kings of other Sultanates in Indonesia. One of them is the kingdom or Sultanate of Sumbawa in West Nusa Tenggara, which was led by the kings of sultans who were in power at that time. At that time, the Sumbawa form of government was a form of government of the Hindu Kingdom, as written in Mantja (2011) that Sumbawa at that time was under the leadership of the Yellow Cloud 
god dynasty. Along with the development of Islam, finally, administration in Sumbawa moved into the regime of the Islamic Sultanate, which began to be led by Dewa Mas Bantan (Sultan Harunurrasyid I) 1674-1702.

Sultan Kaharuddin III was the last period for the Sultan's leadership in Sumbawa. This is because, in 1950, the kingdom of Sumbawa declared itself merged with the Republic of Indonesia (Mantja, 2011). Before joining RI, Sumbawa was incorporated in the State of East Indonesia (NIT), which was formed in 1947. The role of Sultan Kaharuddin III in leading the Sultanate in his time so that his role in the formation of the Republic of Indonesia was exciting to be explored more deeply by researchers. This is because during his presidency was a transitional period between the Republic of Indonesia and the Sultanate.

The tracing of Kaharuddin III will be the main factor in this research because this is where the possibility of the political communication phenomenon of the Sultanate of Sumbawa can be seen from its base. This is related to the leadership that is owned by individuals, can indirectly have an impact on his leadership style. Raph White and Ronald Lippitt (Winardi, 2000) said that the leadership style is a style used by a leader to influence the group or society being led. So to become a leader requires the principal capital that is natural and eccentric capital. Both, if owned by a leader, it will make the person acceptable to the community. Natural wealth includes ability, capability, and personality, while foreign capital includes acceptability, which is an attitude of environmental acceptance towards the leader (Teguh, 2008).

Researchers try to see how the political communication that characterizes the Sultan of Sumbawa in leading in his heyday by using phenomenology. Then from that concept, can it collaborate at this time with two different leaders of the era with the idea of political communication. The figure of the leader must be able to do something for his people or the community that is led to dynamic the city and its goals (Johnson, 1994).

\section{B. LITTERATURE REVIEW}

\section{Government Systems Used by Various Countries.}

The government system consists of several methods, namely presidential, semipresidential, parliamentary, communist, liberal democracy, and others. According to Assiddiqie (2012) in Novianti (2013), that the government system adopted is now formulated into four models, namely the American, French, English, and Swiss models. America represents presidential, British adheres to parliamentary, France has its own uniqueness because it adheres to the Hybrid System system, then Switzerland is also called the Collegial System that has differences with the presidential and parliamentary system. directly by the people. The president holds power as head of state and head of government. The president is also the sole executive leader, and the president also chooses his ministers to help carry out the duties of a president (Sofian, 2007). 
The parliamentary system places government leaders and heads of state separately. The position of head of state is usually pinned to the king, queen, or president, then the head of government is carried out by the prime minister. Large countries in Europe adhered to this system, such as the United Kingdom and the Netherlands, while in Asia, such as Malaysia, Brunei, India, Singapore, and Thailand adopted it (Novianti, 2013). The first parliamentary characteristic is that the head of state is symbolic and has limited political influence. Second, the chosen prime minister can be dismissed by the local parliament. Then third, parliamentary elections are determined by the head of state through elections and based on advice from the prime minister. So from this, the executive position becomes under the situation of parliament.

Indonesia currently uses the practice of presidential government systems, but before that, Indonesia had changed the system. Indonesia is noted to have used the parliamentary system. Feith (1962) in (Sofyan, 2007) wrote that during the four years of adopting the Indonesian parliamentary system, 33 times had experienced a change of government system. Until now, Indonesia has used a pure presidential system because, at the time of the transition, the presidential system from 1998-2004 had not yet been implemented.

\section{Sultanate as a Government System}

If you want to see the extensive modern imperial government system, then we will try to look in the mirror with the governance system of Brunei Darussalam and Malaysia. Brunei Darussalam is one of the countries that became a former British colony. Brunei is also a country led by the sultanate until now Brunei is a country in Southeast Asia led by a Sultan (Talib, 2013). So it is not surprising that Brunei is the only country that uses the whole Islamic sultanate system in Southeast Asia. Brunei had gained its independence from the British colony in 1984, freedom gained from Britain in 1984, did not produce representative government institutions, but basically led to the consolidation of the monarchical system of government (Singh, 1988).

The current system of government adopted by Brunei is an absolute monarchy, Brunei is led by the Sultan of Brunei as the head of state and head of direct government. The Sultan of Brunei, who led was taken from the lineage of the rulers of Brunei in the 14th century, so the Sultan of Brunei, who is now Sultan Haji Hassanal Bolkiah Mu'izzaddin Waddaulah is directly a derivative of that (Mclellan \& Chin, 2016). Not a few experts doubt the existence of absolute monarchy lasted for a long time. As stated by Huntington (1968), he argued that the royal government would not be able to withstand the pressures of the modern state.

After independence from Britain in 1984, the Sultan had absolute power, but at that time, the Sultan considered the importance of creating government institutions that could assist him in carrying out governance in a modern country. So in 1984, a cabinet government system was established, but in the cabinet, the Sultan's power was not removed or remained absolute. In the ministry, the Sultan still serves as head of 
state, prime minister, finance minister, and domestic minister simultaneously (Leake, 1990).

Huntington (1968) argues that absolute monarchy can be considered as a suitable type of regime in the modern era. According to him, centralization of power, although beneficial for socio-economic changes, but did not provide sufficient stimulus for the Sultan to expand their social base and accommodate the demands of new social groups created through the process of modernization (Talib, 2013). But the monarchy system of government is a sound system for the countries in the Middle East. The strong centrality of monarchical power can be seen as a good sign, especially in the first step of forming a State when policies must be made quickly (Anderson, 1974 \& Anderson, 1991).

Referring to the research of Peter Carey (1989), he explained how the leadership revolution in the context of government, he wanted to catch a glimpse of the contemporary view of the Yogyakarta court in the late 18th and early 19th centuries, and to consider the extent to which the characteristics of war were inherited by its founder might have an influence on subsequent history. Intrigues had already occurred when Mangkubumi met Sunan Pakubuwana III (1749-88) in the village of Jatisari, halfway between Giyanti and Surakarta on 15 February 1755 he was asked by the Surakarta authorities to make a choice. Between "Tradition" and "Modernity" is related to his new court in Yogyakarta.

The political impact seen when Angger Arubiru was codified in April 1773, was to empower the governor (prime minister) of each kingdom to confiscate clothing items that were prohibited for the subject of the ruler, and the law of the shelter applicable if other court subjects wore clothing such as that is when visiting the capital (Ricklefs, 1974).

This research by Carey (1989) discusses explicitly the political communication process that occurs between Surakarta and Yogyakarta in terms of differences in administrative court policy. These processes have an impact on the continuity of government that arises in the two kingdoms in court proceedings. Yogyakarta prefers traditional justice, while Surakarta prefers truth based on modernity. The Sultan may have been considered a good symbol of local identity in the era of Indonesian autonomy. It was a component of the communitarian change in Indonesian politics after the collapse of the New Order. Characters are being revived or created at high speed, especially at the district level.

Klinken (2007) describes the return of the Sultans in local politics in Indonesia. In his writings, there are several kingdoms or sultans who were resurrected until 2002. Identities that are being revived or created with high penetration, especially at the district level. According to Klinken, the return of the Sultan is refreshing to study because the metaphor of the Sultan is still prevalent in the scope of observers in Indonesia, and this is a strange thing (Loveard, 1999).

In this case, the Sultan has long assumed an insignificant role here; they only represent the organized state of the developing islands (Andaya 1992 \& Werren 1981). However, the Netherlands gradually tied them to a royal foundation until they became 
mere intermediaries in a mode of government, which was said to be indirect government (Houben 1994, Larson 1987, \& Locher 1994).

\section{Political Communication According to Experts.}

The broad understanding of political communication gives rise to a variety of opinions about political communication. According to Fagen (Nasution, 1990), political discussion is communication that occurs in the political system than between the system and its environment. Then Galnoor in (Nasution, 1990) also explained that political debate is a political infrastructure, which is a combination of various social correlations of how information relating to joint ventures and power relations comes into circulation. Then (McNair, 2003) provides a more explicit description of political communication that is all communication that has political intentions, he argues that all political conversation is entered into the understanding of political communication. The interview is not only verbal in the form of writing but also includes non-verbal such as body gestures, symbol designs to appearance styles.

Indrawan (2017) describes political communication as a study of science that observes the activities and behaviors of communication that have a political nuance, political impact, or influence on political behavior. In a democratic system, political communication can make public opinion move freely because it is caused by equal roles. So that political communication can change views into public view in accordance with the interests of the elements that drive the conversation. This study also shows how important the media is in the process of political communication. Developments have begun to change, the media has not only become a channel but has moved forward to become a communicator, how the media can arrange the form of comments, statements, questions, and editorial itself as needed.

Political communication includes paralinguistics such as body language and political actions in the form of boycotts and protests (Graber, 2005). Graber views political communication in the context of political socialization as a process of learning, acceptance, and approval of customs or rules, structures, and environmental factors that influence civic life. He occupies a prominent position in social and political life because it can affect the quality of interaction between the people and the authorities.

Chaffee in Kaid (2004) defines that, "Political communication is the role of communication in the political process" (political communication is the role of communication in the political process) but in all political activities. In his writings, Chaffee (2001) describes the changes in new technology that will affect political communication. Chaffee explained the effects of a media (The Era of Media Effects) on the extent to which it would affect changes in political communication.

\section{RESEARCH METHOD}

The use of non-Western paradigms is a preference in researching or observing realities, especially in Asia. This is because most academics examine a phenomenon from a Western perspective. The use of this non-Western paradigm is used by 
researchers because it is felt that it can include parameters on the basis of interpretive models as a manifestation procedure of reality that is inclusive of the others.

This research method uses qualitative research methods with phenomenology as the science of interpreting social reality. Phenomenology is something that touches with a system of consciousness as experienced itself so that then phenomenology is very much related to knowledge emblazoned in experience or interpreted as selfexperience of a thing (Raco, 2010).

This qualitative research is an option because it can enrich qualitative research as support for developing non-Western school studies. The selection of phenomenology is considered quite important for this research because it is in direct contact with how to address an existing culture. So the phenomenological assumption is a tradition of people to interpret his personal experience and then try to understand it (Littlejohn \& Foss, 2009).

Analysis of the data that will be used in this study is a narrative analysis model. Griffin (2006) argues that a narrative review is a form of rhetoric and common sense that makes sense of the translation that unites theorized descriptions of an event with its story. Narrative summary is also guided by texts and practices in social life. The narrative is also a way for people to organize their daily practices and subjective understanding, and the story is present in both text and oral form to uncover knowledge and quality of life (Neuman, 2014).

\section{RESULTS AND DISCUSSION}

\section{Fundamental Islamic Values of the Sumbawa Sultanate Government System.}

The distribution of tassawuf affected almost all levels of Sumbawa society. Understanding about the ulu no canceled Sembayang no putes (Wudu is not canceled, prayer is not broken) is one of the proofs of acceptance of Islamic teachings in the scope of the ordinary people of Sumbawa. This was for the sake of hiding from the situation and condition of the Sumbawa people who were still under the influence of Majapahit, the Hindu, Animism, and Dynamism rulers. So from these characteristics of Islamic values that underlie the leadership of Sultan Kaharddin III in running the government.

In his leadership, the Sultan placed the ulama's position outside the leadership structure but became a place of final consideration in deciding policy. Kaharuddin III is said to have positioned religion above tradition and culture. He utilizes culture and tradition as a tool to approach the public. The culture and traditions that have existed in Sumbawa for generations have been influenced by Hinduism and successfully reconstructed their meaning in accordance with the teachings of Islam so that the values of Islam and the traditions of the Sumbawa people can still be run in tandem.

The Sumbawa Sultanate is said to be a dynasty leadership system as well as other Sultanates. However, in the leadership of Sultan Sumbawa until Kaharuddin III, the position of a Sultan is not necessarily bequeathed to his biological child. This was seen from the historical trajectory of the Sultan of Sumbawa's leadership. The appointment of a Sultan is not necessarily due to lineage, strength, and authority. But the religious factor becomes a reference as a leader. Then all of these things must also be seen from 
the views of the scholars of that era. From this factor that became the difference in the Sultan Sumbawa's government system with the other sultanates was how the communication was carried out in determining the successor to the throne, this was considered capable of reducing conflicts overpower struggles in the future.

In carrying out their lives, the Sumbawa people firmly use Islamic principles, as does the Sultan. In running the government, Sultan Kharuddin III used policies or guidelines in accordance with Islamic life. For example, in carrying out a good collaboration with other sultanates, even with the Netherlands, the Sultan was guided by Islamic guidelines. Sumbawa people are terrified of illicit goods obtained from buying and selling, Islam also forbids usury so that the Sultan's cooperation system uses a profit-sharing scheme.

Sultan Kaharuddin III also used the values of Islamic teachings in the basic structure of social organizations in government. In this case, the organizational structure is not limited to the lineage, whether it is nobles, princes, rich people, and nobles. But they still respect the king for holding fast to the value that the leader is an extension of the almighty God and must also be recognized appreciated. So in the absence of such restrictions, the Sultan intends that in the formulation of a decision and policy, there is no fear and not hesitate in issuing an opinion because that is caused by differences in social status.

\section{Utilization of Arts and Culture as Political Communication Media.}

Sultan Sumbawa utilizes Sumbawa art because it is considered able to make anyone who enjoys it can make it comfortable and peaceful; this is because Sumbawa art contains Islamic values in it. For example, in musical skills, Ratib and Zapin have the power of lyrics from Islamic values. Other art forms of work that do not draw or accentuate the elements of living things so that in Sumbawa do not realize the art of sculpture, drawing, and mask. This art is repeated repeatedly to accompany essential guests in the hope of influencing the psychological audience of the audience.

Giving a horse to Sukarno could also be an interpretation of political communication at the time to carry out political dialogue in order to negotiate and conduct political lobbies related to the Sultan of Sumbawa's goals. Horse racing is a tradition and culture of Sumbawa, which is very popular in the Sumbawa community, even today it is still being carried on for generations by the Sumbawa people to this day. The symbolization of horses in Sumbawa has been steady and thick since the days of the war, so that Sultan Kahurddin III also used horse racing as a glue for the people of Sumbawa. Not only Soekarno but the chairman of Masyumi Sumbawa at the time also had a racehorse as a form of participation in the traditions and culture of the Sumbawa people. Isa Sabu, as chairman of the Masyumi at that time, was very fond of Sumbawa horse racing.

In addition to using the tradition of horse racing, Sultan Kaharuddin III also always slipped art before conducting a crucial meeting with figures who had interests in the Sumbawa sultanate. Culture in the form of a dance art was also carried out as a tool to strengthen the community and the elite of the government at that time to meet 
in a container wrapped in nuances of Culture. Usually, the Palace Hall was opened to the public as an open venue.

One form of political communication of Sultan Kaharuddin III was also indicated in the Karaci art tradition in Sumbawa. This art almost resembles the art or culture of Presean Lombok society. This is thought to be the result of cultural acculturation due to the political relations between the two regions. This illustrates that in the leadership of Sultan Kaharuddin, III was able to embrace and unite the people of Lombok who migrated to Sumbawa as well as a form of closeness towards them. It is hoped that in leading, there will be no oppression or even fear from Lombok residents who migrate to Sumbawa so that the leadership wheel can run well. Aside from being a place of communication, this art also has a philosophy that emphasizes the nature of courage and courage seen from the game that contains the buying and selling of blows. The forgiving nature of the people of Sumbawa is shown after the performance; there is no grudge between the two of them.

The use of tradition as the glue of the Sultan's society and family is also one of the unifying tools of the people and the Sultan, seen in the traditional event "Turen Berang" by the Sultan's family. This event is a customary procession when performing circumcision or circumcision. Turen was furious when the child of Sultan Kaharuddin III showed a circumcision procession and was seen attended by all levels of Sumbawa society.

The use of tradition and culture by Sultan Kaharuddin III as a medium of political communication can be said to be inseparable from the function of a tradition for the Sumbawa people. The traditions and customs of the Sumbawa people are as a means of an agreement to create local wisdom in the community, which certainly has an excellent function for the survival of the Sumbawa people. Among other features, it is manifest or over. Visible features and latent functions are called hidden functions

\section{Parenti' Tau Samawa (Life Guidance) as a Form of Political Communication Approach Sultan Kaharuddin III.}

The leadership of Sultan Kahauddin III, while holding the position of Sultan Sumbawa, always prioritized kinship and kinship between each other. This attitude cannot be separated from the primary foundation as the character and philosophy of life of the Sumbawa people. The Sumbawa people and their leaders always apply this approach to interacting well with local communities, even in political matters. The Sultan, as the highest leader in Sumbawa, must be a role model for his people, so the Sultan upholds the customs and Rappang Tau Samawa.

The history of Sumbawa's leadership in its existence either in the pre-Sultanate era until now, its leaders can always create peace in prosperity because this comes from the great shame of the Sultan or in his Sumbawa language (ilaq). The power of principle is that the hands above, rather than the hands below, have been used long ago by the Sultan. In communicating with the higher-ups and with the community, there is a procession called Tokal Adat and musakara. This is done if there are problems that concern the survival of the Sumbawa community both in the realm of adat, as well 
as government and the like. After that, the views of the ulema are always the last reference in consideration of the policy.

Sultan Sumbawa Kaharuddin III held fast to the necessary foundation of Sumbawa's philosophy of life, "Adat Barenti ke Syara', Syara' Barenti ke Kitabullah," which means that there should be no conflict between adat and Islam. so this absolute benchmark becomes the primary foundation for the Sultan's leadership in leading his people. This is so that customs which contradict the Syara' law can not be used, then the Syara' law must be prioritized.

Democracy in Sumbawa has been carried out since the previous king, and the Democratic System was evident during the reign of Sultan Kaharuddin III. At that time, the order of government rested on the Sultan as a system that included custom, government, and law. Then the Sultan, as well as the leader of adat and act, but the highest customary decision was not made alone but produced Telu minister who coordinated Pangantong Dua Olas. Then the Pangantong Dua Olas consisted of Mamanca Lima and Lelurah Pitu. However, every announcement to the people always begins with the phrase "Kasuka Dewa Masmawa and Tana Samawa." This sentence illustrates that the position of the king or Sultan of the ministers, with the people, led united and synergized in a strong determination to build themselves, others and their environment.

The Sultan has 4 conditions in his decision making known as the "Condition Four." This requirement is a simple phrase that binds the community, which means that all levels of Sumbawa society are not immune from the law. This fourth requirement is "Kelek, datang - suru, lalo-eneng, beang - beang, tangko" which means how firmly and resolutely implements community law observance. When called, must come, when told to go, when asked to give, and when given, must be received. This requirement is not an arbitrary one but a condition that is full of careful consideration for the sake of Tau Samawa.

Sultan Kaharuddin III followed the philosophy used by his predecessors and used to run his government. The Sultan and other local leaders emphasized their people to be able to maintain the "10 Saling (Mutual)", namely:"Saling-pediq, Salengsayang, Saleng-saduq, Saling -sakikiq, Saling-tulung, Saling-satingi, Saling-jango, Salengsatotang, Saleng-beme, Saling-santurit.

\section{F. CONCLUSION}

Based on the results of the research that has been done it can be concluded that the political communication carried out by Sultan Sumbawa during the reign of Sultan Kaharuddin III was first to use a local approach based on the values of Islam that had been reconstructed into the form of Sumbawa cultural values. Second, using the artistic and adat method of tana Sumbawa as a form of political communication in establishing relations with external and internal publics, and thirdly, the Sultan uses Parenti Rapang Tau Samawa or the philosophy of life of the Sumbawa people as a basis for the use of his political communication practices both in establishing relations with his people to in running his government. 
The use of the three initial foundations is the main foundation of Sultan Kaharuddin III in running the government and using it as a form of his political communication practices. It was the Sultan's strategy to establish a political relationship with the external and internal public. This method was carried out by the Sultan as well as a form of cultural preservation, customs, and Rapang Tau Samawa in carrying out his social life. The use of this strategy is also practiced so that the Sumbawa people do not forget their main foundation in running a social life or in running a government. 


\section{References}

1. Achmad, W.A. (2016). Politik dalam Sejarah Kerajaan Jawa. Araska Publisher Yogyakarta

2. Andaya, Barbara Watson (1992). 'Political development between the sixteenth and eighteenth centuries,' in Nicholas Tarling (ed.), The Cambridge History of Southeast Asia: from c. 1500 to c.1800, pp. 58-115. Cambridge: Cambridge University Press.

3. Anderson, B. (1983). Imagined Communities: Reflections on the Origin and Spread of Nationalism, London: Verso.

4. Anderson, L. (1991). 'Absolutism and the Resilience of the Monarchy in the Middle East', Political Science Quarterly, Vol.1, No.1.

5. Carey, P. (1986). Yogyakarta: From Sultanate to Revolutionary Capital of Indonesia. The Politics of Cultural Survival, Cultural Survival

6. Chaffee, S. (2001). Studying The New Communication Of Politics. Political Communication, 18 (2), 237-244.

7. Graber, D. A., \& Smith, J. M. (2005). Political Communication Faces The $21^{\text {st }}$ Century. Journal of Communication, 55(3), 479-507.

8. Griffin, Em. (2006). A First Look at Communication Theory (6th ed.) New York: McGraw-Hill.

9. Huntington, Samuel P., 1968. Political Order in Changing Societies, New Haven and London: Yale University Press.

10. Houben, Vincent J.H. 1994 Kraton and Kumpeni : Surakarta and Yogyakarta, 18301870. Leiden: KITLV.

11. J. Mclellan, \& GVS Chin, 2016. Introduction: English in Brunei Darussalam World Englishes, Vol. , No. , pp. 492-496, Wiley Online Library

12. Johnson, D.W. (1994). Joining Together: Group Theory and Group Skills.3rd Edition Englewood Cliffs: Prentice Halls.

13. Kaid, Lynda Lee. 2004. Handbook of Political Communication Research. New Jersey: Lawrence Erlbaum. Associates, Inc.

14. Larson, George 1987 Prelude to Revolution: palaces and politics in Surakarta 1912-42. Dordrecht: Foris.

15. Leake, D., 1990. Brunei: The Modern Southeast Asian Islamic Sultanate. Kuala Lumpur: Forum.

16. Littlejohn, S. W \& Foss, K. A. (2009). Teori Komunikasi Edisi 9. Jakarta. Salemba Humanika.

17. Locher, Scholten, Elsbeth, (1994). Sumatraans sultanaat en koloniale staat : de relatie Djambi-Batavia (1830-1907) en het Nederlandse imperialisme. Leiden: KITLV

18. Loveard, Keith (1999). Suharto: Indonesia's last sultan. Singapore: Horizon Books

19. Mantja Lalu, (2011), Sumbawa Pada Masa Lampau, cetakan kedua, Sumbawa: CV Samratulangi

20. McNair, Brian. (2003). An Introduction to Political Communication. London dan USA: Routledge.

21. Nasution, Zulakarimen. (1990). Komunikasi Politik: Suatu Pengantar. Jakarta: Ghalia Indonesia.

22. Neuman, W. Laurence. (2014). Social Research Methods: Qualitative and Quantitative Approaches. New York: Pearson.

23. Novianti Cora. E. (2013). Demokrasi dan Sistem Pemerintahan. Jurnal Konstitusi. Volume 10 No. 2. Universitas Moch. Sroedji Jember.

24. Prof. Effendi Sofian (2007). Mencari Sistem Pemerintahan Negara. Makalah Orasi Ilmiah Pada Dies Natalis. Unversitas Gadjah Mada Yogyakarta 
25. Raden, M. J Indrawan. (2017) Dampak Komunikasi Politik Dan Opini Publik Terhadap Perilaku Masyarakat. Fakultas Ilmu Sosial \& Ilmu Politik. UPN Veteran Jakarta. WACANA, Volume 16 No. 2.

26. Raco, J. (2010). Metode penelitian kualitatif: jenis, karakteristik dan keunggulannya.

27. Ricklefs, M. C. (1974). Jogjakartaunder Sultan Mangkubumi 1749-1792: a history of the division of Java. London: Oxford University Press. (London Oriental Series, XXX.

28. Sahreza, M. (2018). Pengertian Komunikasi Politik. ResearchGate.Net Publication

29. Singh, Ranjit, 1988. 'Brunei Darussalam in 1987: Coming to Grips with Economic and Political Realities', Southeast Asian Affairs 1988. Singapore: ISEAS.

30. Talib S Naimah, 2013.Brunei Darussalam: Kesultanan Absolut Dan Negara Modern. Kyoto Review Of Southeast Asia Issue : Monarchies In Southeast Asia

31. Teguh, A. (2008). Kepemimpinan professional, pendekatan leadership games.Yogyakarta: Gaya Media

32. Van Klinken, G. (2007). Return of the sultans: The communitarian turn in local politics. The Revival of Tradition in Indonesian Politics (pp. 169-189). Routledge.

33. Warren, James Francis (1981). The Sulu Zone 1768-1898: the dynamics of external trade, slavery, and ethnicity in the transformation of a Southeast Asian maritime state. Singapore: Singapore University Press.

34. Winardi. (2000). Kepemimpinan dalam manajemen. Jakarta : Rineka Cipta 